\title{
Calcium signaling in hepatitis B virus infection and its potential as a therapeutic target
}

\author{
Fanyun Kong ${ }^{1}$, Fulong Zhang ${ }^{2}$, Xiangye Liu ${ }^{1}$, Suping Qin ${ }^{1}$, Xiaoying Yang ${ }^{1}$, Delong Kong ${ }^{1}$, Xiucheng Pan³, \\ Hongjuan You ${ }^{1 *}$, Kuiyang Zheng ${ }^{1,4}$ and Renxian Tang ${ }^{1,4^{*}}$ (D)
}

\begin{abstract}
As a ubiquitous second messenger, calcium ( $\mathrm{Ca} 2+)$ can interact with numerous cellular proteins to regulate multiple physiological processes and participate in a variety of diseases, including hepatitis B virus (HBV) infection, which is a major cause of hepatitis, fibrosis, cirrhosis, and hepatocellular carcinoma. In recent years, several studies have demonstrated that depends on the distinct $\mathrm{Ca} 2+$ channels on the plasma membrane, endoplasmic reticulum, as well as mitochondria, HBV can elevate cytosolic Ca2+ levels. Moreover, within HBV-infected cells, the activation of intracellu$\operatorname{lar}$ Ca2+ signaling contributes to viral replication via multiple molecular mechanisms. Besides, the available evidence indicates that targeting Ca2+ signaling by suitable pharmaceuticals is a potent approach for the treatment of HBV infection. In the present review, we summarized the molecular mechanisms related to the elevation of Ca2+ signaling induced by HBV to modulate viral propagation and the recent advances in $\mathrm{Ca} 2+$ signaling as a potential therapeutic target for HBV infection.
\end{abstract}

Keywords: Hepatitis B virus, Calcium signaling, Infection, Therapy

\section{Background}

The chronic infection of the hepatitis B virus (HBV) is a public health concern and could cause different forms of liver diseases, including hepatitis, fibrosis, cirrhosis, and hepatocellular carcinoma (HCC) around the world [1]. Despite the reduction in carriers of HBV surface antigen due to the use of vaccines, more than billions of people are still suffering from HBV infection. Because HBV is a small DNA virus, the virus heavily depends on host cell factors to facilitate its replication [1, 2]. Calcium $(\mathrm{Ca} 2+)$ is a ubiquitous second messenger. When $\mathrm{Ca} 2+$ flows into cells, it can interact with numerous proteins to control

\footnotetext{
*Correspondence: youhongjuan_00@163.com; tangrenxian-t@163.com 1 Jiangsu Key Laboratory of Immunity and Metabolism, Department of Pathogenic Biology and Immunology, Xuzhou Medical University, Xuzhou 221004, Jiangsu, China

Full list of author information is available at the end of the article
}

a variety of physiological processes, including survival, proliferation, apoptosis, and autophagy [3, 4]. Besides, the ion was also involved in many different kinds of diseases, such as cancer and viral infection $[5,6]$. Especially, the accumulating evidence has highlighted that $\mathrm{HBV}$ can modify $\mathrm{Ca} 2+$ signaling to create a cellular environment to facilitate its infection [7-9]. Furthermore, the dysregulations of intracellular $\mathrm{Ca} 2+$ signaling mediated by the ion channels located in the plasma membrane (PM), endoplasmic reticulum (ER), and mitochondria are mainly responsible for the alteration of $\mathrm{Ca} 2+$ homeostasis mediated by the virus [7, 10-12]. Here, we summarize the available data associated with HBV-dependent elevation of intracellular Ca2+ signaling to modulate viral replication and the therapeutic potential of targeting Ca2+ signaling to inhibit HBV infection.

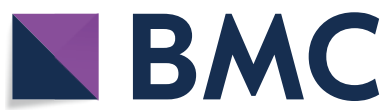

(c) The Author(s) 2021. Open Access This article is licensed under a Creative Commons Attribution 4.0 International License, which permits use, sharing, adaptation, distribution and reproduction in any medium or format, as long as you give appropriate credit to the original author(s) and the source, provide a link to the Creative Commons licence, and indicate if changes were made. The images or other third party material in this article are included in the article's Creative Commons licence, unless indicated otherwise in a credit line to the material. If material is not included in the article's Creative Commons licence and your intended use is not permitted by statutory regulation or exceeds the permitted use, you will need to obtain permission directly from the copyright holder. To view a copy of this licence, visit http://creativecommons.org/licenses/by/4.0/. The Creative Commons Public Domain Dedication waiver (http://creativeco mmons.org/publicdomain/zero/1.0/) applies to the data made available in this article, unless otherwise stated in a credit line to the data. 


\section{The role and molecular mechanisms associated with HBV on elevating intracellular $\mathrm{Ca2}+$ levels}

The regulation of cytosolic $\mathrm{Ca} 2+$ signaling mainly depends on the distinct ion channels located in the PM, ER, as well as mitochondria [3]. For example, relies on voltage-operated $\mathrm{Ca} 2+$ channels (VOCCs) and $\mathrm{PM}$ store-operated $\mathrm{Ca} 2+(\mathrm{SOC})$ channels, the ion enters the cells. Conversely, the PM Ca2+ATPase (PMCA) channels and $\mathrm{Na}+/ \mathrm{Ca} 2+$ exchanger (NCX) extrudes the ion from the cytoplasm to the extracellular space. In the cells, $\mathrm{Ca} 2+$ sensors and sarco/endoplasmic reticulum ATPase (SERCA) pumps Ca2+into the lumen of ER, from where $\mathrm{Ca} 2+$ is released via inositol 1,4,5-trisphosphate receptor channels (IP3R) and ryanodine receptor (RyR). In addition, mitochondria takes up $\mathrm{Ca} 2+$ through voltage-dependent anion channel (VDAC) in the outer mitochondrial membrane (OMM) and the mitochondrial $\mathrm{Ca} 2+$ uniporter (MCU) complex in the inner mitochondrial membrane (IMM). Moreover, it extrudes $\mathrm{Ca} 2+$ via mitochondrial NCX (mNCX) [4]. If $\mathrm{Ca} 2+\mathrm{accu}-$ mulation is overwhelmed in the mitochondrial matrix, the ion is capable of activating the mitochondrial permeability transition pore (mPTP), a non-selective channel across the inner and outer membranes of mitochondria, to transfer $\mathrm{Ca} 2+$ and other small molecules to the cytoplasm.

In hepatocytes, the increase of cytosolic $\mathrm{Ca} 2+$ is mainly from the extracellular space, ER, and mitochondria. Among HBV-encoded proteins, HBX is found to be responsible for inducing extracellular $\mathrm{Ca} 2+$ influx [11], and the effect of HBX on Ca2+ entry into the cytoplasm from the extracellular space is mainly dependent on SOC channels. The best-characterized SOC channel is the $\mathrm{Ca} 2+$ release-activated $\mathrm{Ca} 2+(\mathrm{CRAC})$ channel [3]. Recently, ORAI channels, such as ORAI1, -2 , and -3 , are identified as key molecular components of CRAC channels $[4,5,13]$. Although HBV does not alter the expression levels of SOC channel components, the latest evidence shows that HBX could bind to ORAI1 [13], and this interaction may be contribute to the influx of extracellular $\mathrm{Ca} 2+$ into the cells mediated by the virus. Consistent with the expectation, the study from Yang et al. showed that compared to control cells, the levels of cytosolic Ca2+ mediated by HBX in ORAI1-E106A (dominant-negative ORAI1 mutant)-expressing hepatoma cells were inhibited [11]. Besides these, Chami et al. showed that HBX had the capability of inhibiting the activity of PMCA in the PM to avoid the Ca2+ outflux, through activating caspase-3, to cleave PMCA protein [14] (Fig. 1). However, except for ORAI1 and PMCA, whether other kinds of ion channels or transporters situated in the PM are involved in the regulation of cytosolic $\mathrm{Ca}+$ levels mediated by HBV is still unknown.
As the largest intracellular Ca2+ storage, ER plays a very important role in regulating cytosolic $\mathrm{Ca} 2+$ levels [15]. Current investigation shows that elevated ER stress is associated with $\mathrm{Ca} 2+$ release from the organelle [16]. HBX is observed to situate in the ER and can induce ER stress [17], and the ER stress mediated by HBX maybe contribute to the release of $\mathrm{Ca} 2+$ from the ER. Similar to HBX, HBV core mutant, PreS1 and PreS2 mutants also induce ER stress $[18,19]$, which maybe also facilitate the flow of $\mathrm{Ca} 2+$ out of the ER. By using different channel inhibitors, $\mathrm{Ca} 2+$ outflow from the ER mediated by HBV was found to be mainly relied on IP3R but not RyR [7]. In addition, the findings from Geng et al. indicate that HBX could bind to $\mathrm{Bcl} 2$ to elevate the cytosolic $\mathrm{Ca} 2+$ levels [20]. However, the detailed mechanisms remain unidentified. Due to the interaction of $\mathrm{Bcl} 2$ with IP3R in ER could block the $\mathrm{Ca} 2+$ release mediated by IP3R [21], it is reasonable to speculate that the interaction of $\mathrm{HBX}$ with $\mathrm{Bcl} 2$ may inhibit the Bcl2-IP3R complex, to activate IP3R and facilitate the release of $\mathrm{Ca} 2+$ from ER. Besides these, it has been reported that HBV could integrate into IP3R genes in HCC tissues, whether the integration affects IP3R-mediated ER release of $\mathrm{Ca} 2+$ in hepatoma cells still unknown [22]. CD36, a major mediator of cellular free fatty acids uptake, is also required to induce the release of $\mathrm{Ca} 2+$ from the ER mediated by HBV [23]. Among the HBV proteins, HBX was considered to be mainly responsible for CD36 overexpression [24]. In addition, CD36 can interact with activated $\mathrm{Src}$ and results in inositol 1,4,5- triphosphate (IP3) production. IP3 further binds to IP3R on the ER and may stimulate $\mathrm{Ca} 2+$ release to reduce ER $\mathrm{Ca} 2+$ storage mediated by HBV, especially by HBX [11, 23] (Fig. 1).

Within the cells, reduced ER Ca2+ storage could activate $\mathrm{Ca} 2+$ sensors or SECAR channels to uptake $\mathrm{Ca} 2+$ $[3,25]$. On the one hand, the $\mathrm{Ca} 2+$ sensor stromal interaction molecule protein 1 (STIM1) situated in the ER could induce the activation of the SOC channels through binding to ORAIl in the PM, and the interaction of STIM1 and ORAIl facilitates the transfer of $\mathrm{Ca} 2+$ from extracellular space into cytosol, and this process is known as store-operated calcium entry (SOCE) [25]. It has been proposed that $\mathrm{Ca} 2+$ influx mediated by HBX may be dependent on the binding of HBX with STIM1-ORAIl complexes [13]. In addition to HBX, HBV PreS2-mutant large surface antigen is also capable of recruiting STIM1resident ER toward ORAIl in PM to promote the interaction of STIM1 with ORAI1 and induce SOCE [26]. On the other hand, the reduced ER Ca2+ storage activates SERCA, which transfers $\mathrm{Ca} 2+$ from the cytoplasm into ER [3]. Although it has been reported to the activation of SERCA is associated with HBV replication [7], the study from Chami et al. showed that HBX can integrate into 


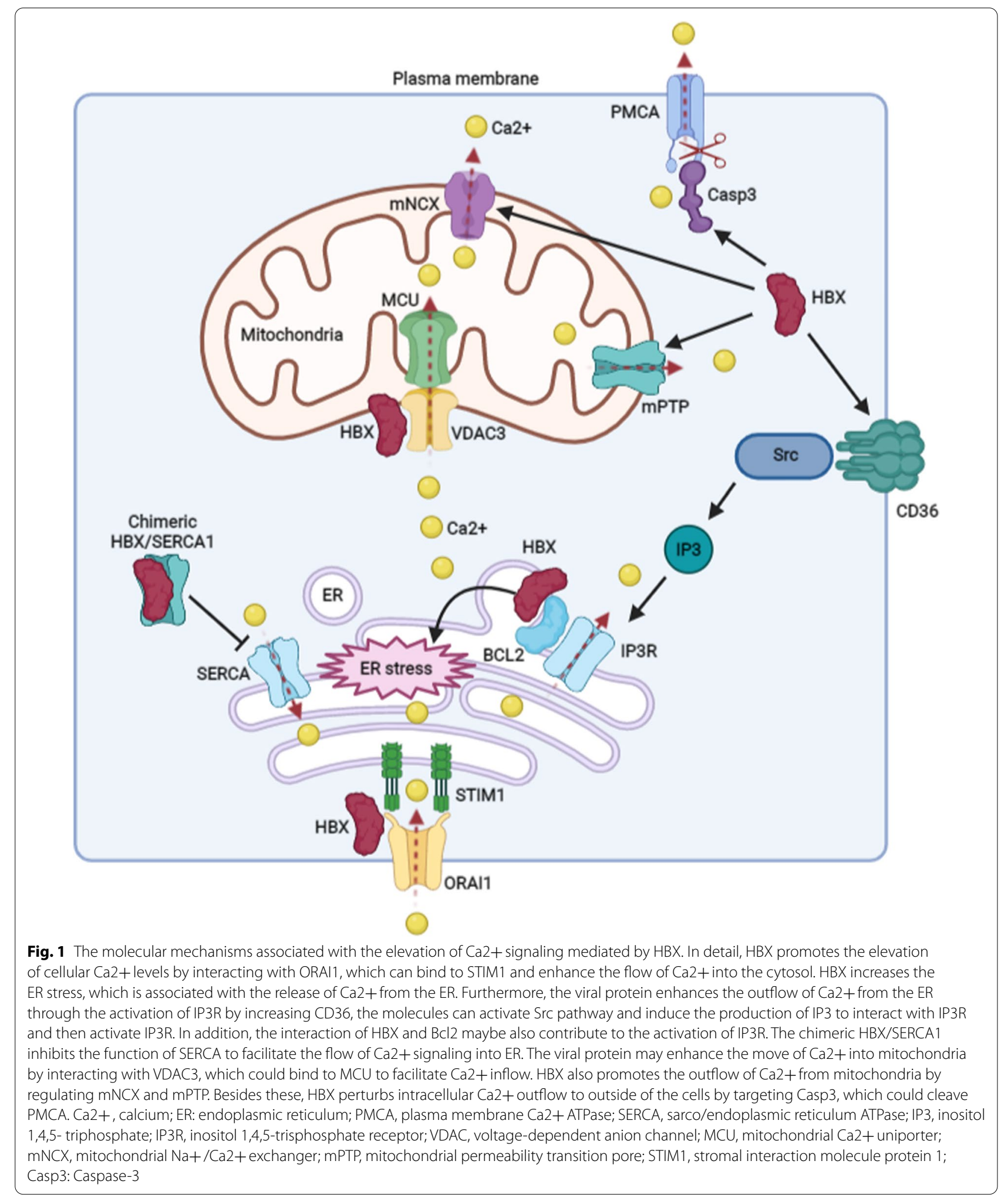


the SERCA1 gene, and forms chimeric HBX/SERCA1 transcripts in HCC tissues. In vitro analysis showed that HBX/SERCA1 proteins localized to ER, and block the function of SERCA1 to induce ER Ca2+ depletion in hepatoma cells [27].

Mitochondria is a vital cellular organelle with the function of participating in the regulation of cellular $\mathrm{Ca} 2+$ signaling to promote the tricarboxylic acid cycle and ATP synthesis [28]. The growing evidence shows that HBX contributes to mitochondrial $\mathrm{Ca} 2+$ uptake [11]. Ca2+ fluxing into mitochondria is mainly dependent on VDAC in OMM, and MCU with interactions of several regulatory subunits, including MICU1, MICU2, and EMRE in IMM $[3,4]$. It has been observed that HBV is capable of increasing MICU1 expression, and HBX could interact with VDAC3 [12, 29] (Fig. 1). The regulation of MICU1 and VDAC3 mediated by the virus maybe facilitate mitochondrial $\mathrm{Ca} 2+$ uptake. Importantly, the findings from Casciano et al. indicates that HBV stimulates mitochondrial $\mathrm{Ca} 2+$ influx during the ion releases from the ER and/or $\mathrm{Ca} 2+$ entry through the SOC channels in the PM. The mitochondrial $\mathrm{Ca} 2+$ uptake is capable of dampening $\mathrm{Ca} 2+-$-mediated inhibition of further $\mathrm{Ca} 2+$ release from ER and/or Ca2+ entry through SOC channel, thereby prolonging $\mathrm{Ca} 2+$ entry into the cytoplasm to increase the levels of cytosolic $\mathrm{Ca} 2+[12]$. Once $\mathrm{Ca} 2+$ is overloaded in mitochondria, mNCX and $\mathrm{mPTP}$ could be triggered to open and transfer $\mathrm{Ca} 2+$ into the cytoplasm [28]. Furthermore, it has been proposed that both $\mathrm{mNCX}$ and mPTP are involved in Ca2+alteration mediated by HBX in mitochondria $[8,30]$. Together, these evidence suggests that HBV, especially HBX, influences the activity of distinct $\mathrm{Ca} 2+$ channels in the PM, ER, and mitochondria to facilitate the regulation of cytosolic $\mathrm{Ca} 2+$ levels. An in-depth understanding of the details associated with the regulation of $\mathrm{Ca} 2+$ channels induced by the virus could help us develop suitable inhibitors to restrict these target channels and facilitate the treatment of HBV infection.

\section{The role and molecular mechanisms associated with Ca2 + signaling on HBV life cycle}

As a partially double-stranded DNA virus, HBV contains 4 overlapping open reading frames (ORFs): $\mathrm{P}, \mathrm{S}, \mathrm{C}$, and $\mathrm{X}$. The P ORF encodes Pol protein. S ORF encodes $\mathrm{S}$, preS1, and preS2 domains to construct the LS (large surface), MS (middle surface), and $S$ (small surface) proteins. Two genes locate in C ORF and are responsible for the expression of $\mathrm{HBc}$ and precore proteins. The $\mathrm{X}$ region is the least ORF, and it is capable of encoding HBX protein. After the virus interacts with the receptor sodium taurocholate cotransporting polypeptide (NTCP), it enters into the cells and uncoated. Sequentially, the genome of the virus was transferred into the nucleus and converted into covalently closed circular DNA (cccDNA). Next, the cccDNA forms a minichromosome and transcripts to 4 lengths of viral mRNA, including $3.5 \mathrm{~kb}$ preC mRNA and pregenomic RNA (pgRNA), 2.4 and $2.1 \mathrm{~kb}$ envelope mRNAs, and $0.7 \mathrm{~kb} X$ mRNA. The preC mRNA encodes precore protein, which is further cleaved and secrets as HBe. pgRNA translates $\mathrm{HBc}$ and Pol proteins as well as acts as a template for viral replication. The 2.4 and $2.1 \mathrm{~kb}$ envelope mRNAs encode LS, MS, and S proteins. Additionally, the X mRNA translates HBX protein. After these viral RNAs translate into HBV proteins, the pgRNA is encapsulated into core particles, and further reversely transcribes into viral DNA. Then, the viral particles containing HBV DNA are enveloped and secret from the cells $[31,32]$.

In the past years, several works have been focused on understanding the role of $\mathrm{Ca} 2+$ signaling mediated by HBV in accelerating its replication. As a virus non-structural protein, HBX plays a critical role in HBV replication [31, 32]. A recent study reports that, via $\mathrm{Ca} 2+$ signaling, fatty acids could promote the stabilization of HBX [33], and this role mediated by fatty acids maybe contribute to the HBV replication. More importantly, several studies have demonstrated that the $\mathrm{Ca} 2+$-dependent signaling mediated by HBX contributes to HBV replication (Fig. 2). Mechanistically, it has been proposed that Pyk2/ Src and FAK signals were involved in the replication of HBV [8, 34]. Inhibition of cytosolic Ca2+ blocks HBXdependent activation of Pyk2/Src and FAK signals, and in turn, inhibits HBV replication. In addition to distinct signals, HBX also could use $\mathrm{Ca} 2+$ signaling to regulate the cell cycle to stall in $\mathrm{G} 1$ to stimulate virus replication [35, 36]. Especially, the alteration of $\mathrm{Ca} 2+$ levels mediated by SOCE, ER, and mitochondria is observed to be involved in the replication of HBV mediated by HBX, because knocking down ORAI1 to block SOCE, inhibiting IP3R situated in ER, or suppressing MPTP located in mitochondria, could restrict HBX-dependent viral replication $[11,35]$.

The innate immune response is the first line of host defense against HBV infection. Binding to the interferon$\alpha / \beta$ receptor, the innate immune molecule interferon (IFN) could initiate Janus kinase/signal transducer and activator of transcription (JAK/STAT) pathways to induce the expression of IFN-stimulated genes (ISGs) to further eliminate the virus [32]. However, HBV has the capability of resisting IFN-mediated innate immunity to facilitate its replication through increasing the expression of intracellular $\mathrm{Ca} 2+$ signaling-modulated proteins, including Calreticulin, an ER luminal protein whose main functions are based on the binding with $\mathrm{Ca} 2+$ in hepatocytes [37]. Detailed mechanisms suggest that Calreticulin mediated by HBV could inhibit IFN- $\alpha$ production 


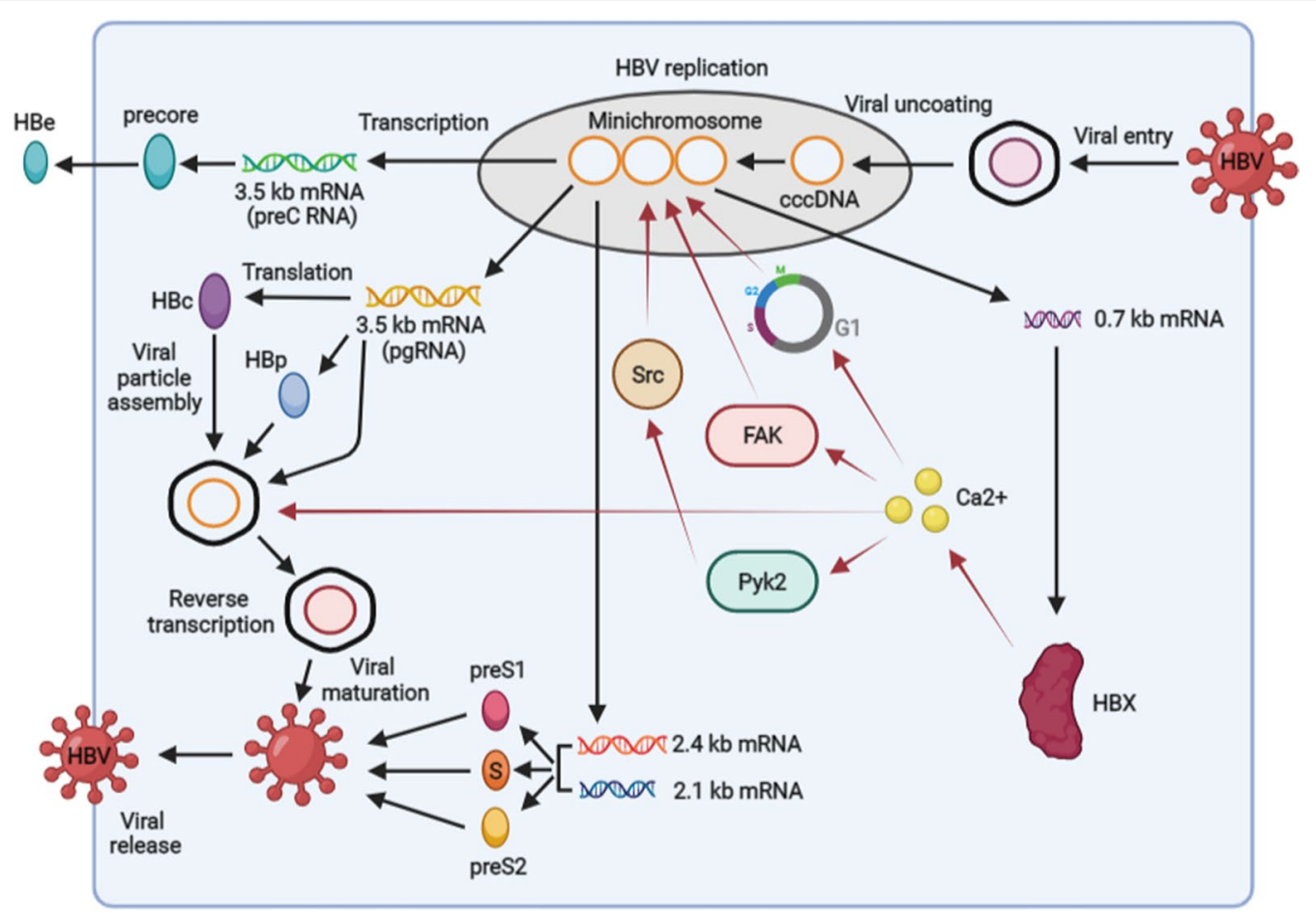

Fig. 2 The molecular mechanisms associated with Ca2+ signaling mediated by HBX to regulate HBV life cycle. HBX elevates the levels of Ca2+ to activate Pyk2/Src and FAK pathways, and regulate the cell cycle to stall in G1 phase to promote HBV replication. In addition, the Ca2+ signaling mediated by HBX facilitates viral core assembly. cccDNA, covalently closed circular DNA; pgRNA, pregenomic RNA

by reducing the nuclear translocation of IFN regulatory factor-7. Moreover, Calreticulin suppresses the antiviral activity of IFN- $\alpha$ is related to the suppression of STAT1 activation and the decrease in the expression of two ISGs, protein kinase $\mathrm{R}$ and 2,5'-oligoadenylate synthetase.

To date, the current studies also demonstrated that increased $\mathrm{Ca} 2+$ mediated by HBX enhanced HBV core assembly (also known as capsid assembly) in hepatocytes [38] (Fig. 2). However, the molecular mechanisms related to HBX-dependent core assembly induced by $\mathrm{Ca} 2+$ signaling were not well explored so far. As a viral polymerase, HBV Pol protein has an important role in viral DNA replication and reverse transcription in the HBV life cycle $[31,32]$. Choi et al. showed that HBV Pol interacted with S100A10, a Ca2+-modulated protein, and the interaction inhibit the activity of HBV Pol and transport HBV Pol to PML nuclear bodies (PML NBs) to inhibit viral replication. In the aspect of mechanisms, the role of S100A10 on the transport of HBV Pol to PML NBs could be regulated by intracellular $\mathrm{Ca} 2+$. Elevated cytosolic $\mathrm{Ca} 2+$ is capable of blocking the effect of S100A10 on the transport of Pol protein to PML NBs [39]. Together, the evidence presented here suggests that the cellular factors controlled by $\mathrm{Ca} 2+$ signaling participate in different steps of the viral life cycle during HBV replication. Therefore, further explore the effect of $\mathrm{Ca} 2+$ signaling and associated molecules on other steps of HBV life may deepen the understanding of $\mathrm{Ca} 2+$ signaling-dependent mechanisms related to viral replication.

\section{Ca2+ signaling as a potential therapeutic target in $\mathrm{HBV}$ infection}

Because of the importance of $\mathrm{Ca} 2+$ signaling in $\mathrm{HBV}$ infection, the increasing evidence has demonstrated that controlling intracellular $\mathrm{Ca} 2+$ or $\mathrm{Ca} 2+$ channels by suitable pharmaceuticals is a potential strategy to control HBV replication (Fig. 3). For instance, chelation of cytosolic Ca2+ with BAPTA-AM [8, 35], and Rubiadin, a regent isolated from prismatomeris connate [40], has a significant antagonistic effect on viral replication. Recently, the emerging evidence indicates that the inhibition of mitochondria channels, including targeting $\mathrm{mNCX}$ channels with CGP37157 [8] or suppressing MPTP with cyclosporine A (CsA) can block HBX-dependent HBV replication [41]. Besides these, treating SERCA with thapsigargin (TG) and cyclopiazonic acid (CPA), or targeting IP3R with U73122, or 2-aminoethoxydiphenyl (2-APB) to restrict the function of $\mathrm{Ca} 2+$ channels in ER $[7,12]$, also have a significant inhibitory effect in HBV replication. Moreover, the inhibition of HBV replication mediated by 


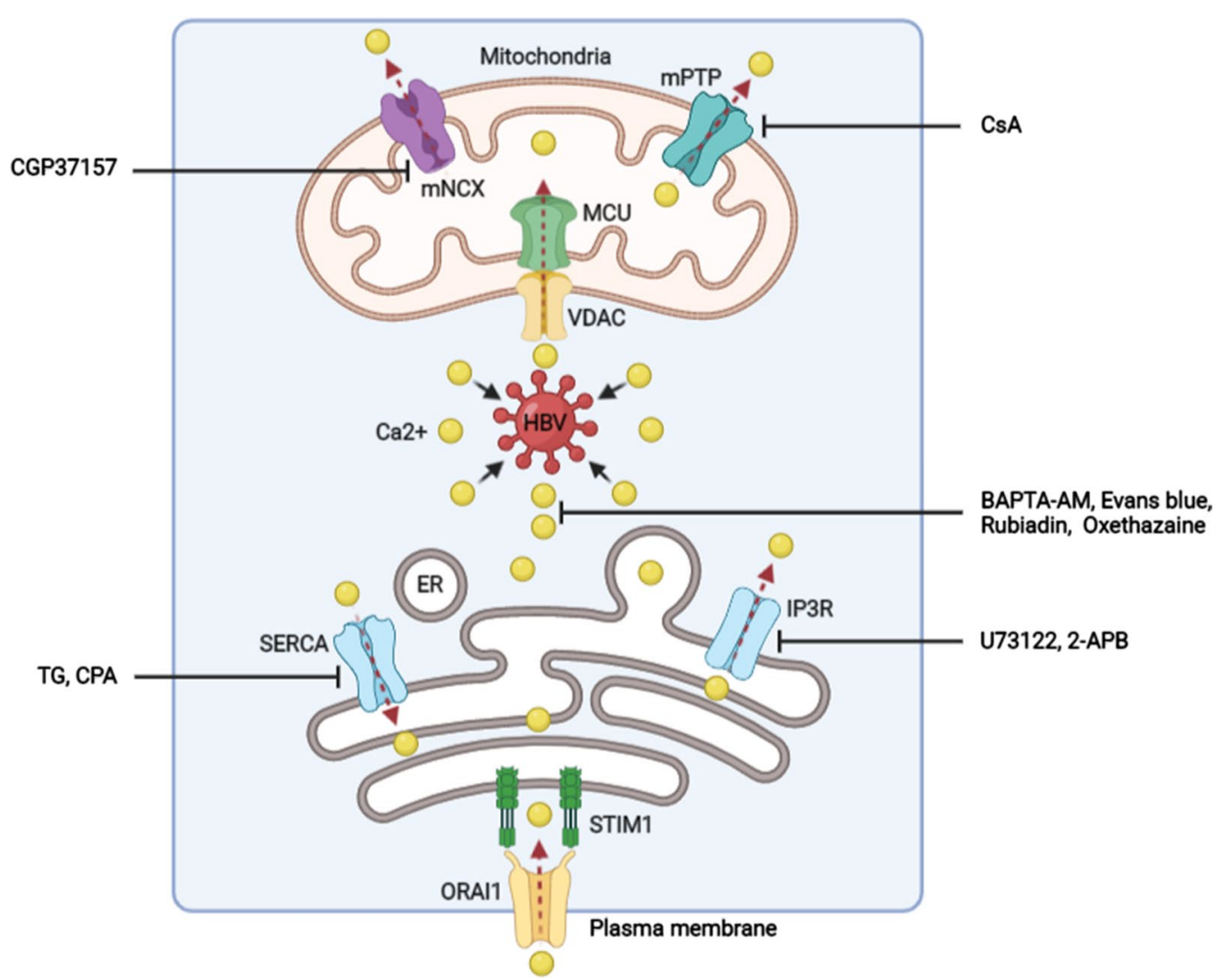

Fig. 3 The pharmaceuticals inhibit HBV infection by targeting Ca2+ signaling. CSA, cyclosporine A; TG, thapsigargin; CPA, cyclopiazonic acid

different pharmaceuticals to target $\mathrm{Ca} 2+$ signaling was associated with the inactivation of Pyk $2 / \mathrm{Src}$ and FAK signals mediated by HBX $[8,34]$.

As mentioned, HBV core assembly is promoted by Ca2+signaling [38]. The work from Choi et al. demonstrates that the inhibition of cytosolic $\mathrm{Ca} 2+$ levels by BAPTA-AM, or block mPTP open in mitochondria by CsA could reduce the assembly of viral core protein in viral-transfected hepatoma cells [38]. Similarly, Xiao et al. show that Evans Blue, an FDA-approved agent used for treating blood-brain barrier disruption, suppresses HBV core assembly via targeting the cytosolic $\mathrm{Ca} 2+$ signaling [42]. Interestingly, both CsA and Evans Blue are also involved in the inhibition of HBV entry into host cells by controlling the binding of viral envelope protein to the membrane transporter NTCP $[42,43]$. Another FDA-approved agent, oxethazaine, is shown to inhibit HBV replication by blocking the self-assembly of HBV core protein as well. Moreover, oxethazaine has the capability of inhibiting the replication of lamivudine/entecavir-dual-resistant and adefovir-resistant HBV mutants. Besides, the reduction of cytosolic $\mathrm{Ca} 2+$ concentration and Pyk 2 activation by oxethazaine [44], is responsible for its inhibition on HBV core assembly.

\section{Conclusions}

The evidence presenting here indicates that HBV can utilize multiple mechanisms to elevate the levels of intracellular $\mathrm{Ca} 2+$. In turn, the increased cytosolic $\mathrm{Ca} 2+$ is capable of facilitating viral replication in several manners. Moreover, the available evidence suggests that the use of different kinds of pharmaceuticals that targeting $\mathrm{Ca} 2+$ signaling is a potent strategy for HBV. Until now, significant progress has been made in identifying the potential targets, including $\mathrm{Ca} 2+$ channels and $\mathrm{Ca} 2+$ dependent proteins, for pharmacological intervention [5]. An in-depth understanding of the activation of $\mathrm{Ca} 2+$ signaling induced by HBV can develop novel therapeutic approaches to control the virus.

Specifically, HBX has been demonstrated to participate in viral replication [31,32], although the exact mechanisms remain not fully elaborated. Our reviewed studies support that the elevation of $\mathrm{Ca} 2+$ signaling and related functions mediated by HBV is mainly dependent on HBX. On the one hand, through regulating the activation and expression of multiple $\mathrm{Ca} 2+$ channels, including ORAI1, IP3R, and mPTP in the PM, ER, and mitochondria (Fig. 1), the viral protein could elevate the levels of $\mathrm{Ca} 2+$ in the cytoplasm. On 
the other hand, HBX contributes to viral replication via $\mathrm{Ca} 2+$ signaling-dependent activation of $\mathrm{Pyk} 2 / \mathrm{SrC}$ and FAK pathways. Based on Ca2+ signaling, $\mathrm{HBX}$ also facilitates core assembly (Fig. 2), despite the detailed mechanisms are not defined. To better understand the role of $\mathrm{Ca} 2+$ signaling in the $\mathrm{HBV}$ life cycle mediated by $\mathrm{HBX}$, more investigations on the complicated interactions between $\mathrm{HBX}$ and $\mathrm{Ca} 2+$ signaling are deserved.

Besides these, our knowledge on the role of $\mathrm{Ca} 2+$ signaling mediated by HBX on viral replication was mainly from the in vitro cellular models. The effect of $\mathrm{Ca} 2+$ signaling on HBX-dependent HBV replication in animal models as well as patients with HBV infection is unknown. Furthermore, although $\mathrm{Ca} 2+$ signaling facilitates HBV replication, the influence of cytosolic $\mathrm{Ca} 2+$ signaling on the development of $\mathrm{HBV}$-associated diseases, including hepatitis, cirrhosis, and HCC, is not well clarified. Therefore, future studies are needed to provide more insights into the biological processes associated with the alteration of $\mathrm{Ca} 2+$ signaling mediated by HBV.

\begin{abstract}
Abbreviations
Ca2+: Calcium; HBV: Hepatitis B virus; ER: Endoplasmic reticulum; IFN: Interferon; ORFs: Open reading frames; cccDNA: Covalently closed circular DNA; pgRNA: Pregenomic RNA; PM: Plasma membrane; PMCA: PM Ca2+ ATPase; VOCCs: Voltage-operated Ca2+ channels; $\mathrm{NCX}: \mathrm{Na}+/ \mathrm{Ca} 2+$ exchanger; SERCA : Sarco/endoplasmic reticulum ATPase; IP3R: Inositol 1,4,5-trisphosphate receptor channels; VDAC: Voltage-dependent anion channel; OMM: Outer mitochondrial membrane; MCU: Mitochondrial Ca2+ uniporter; IMM: Inner mitochondrial membrane; mNCX: Mitochondrial NCX; mPTP: Mitochondrial permeability transition pore; CRAC: Ca2 + release-activated Ca2+; IP3: Inositol 1,4,5-triphosphate; STIM1: Transmembrane stromal interaction molecule protein 1; CsA: Cyclosporine A; TG: Thapsigargin; CPA: Cyclopiazonic acid.
\end{abstract}

\section{Acknowledgements}

The figures were created using BioRender (https://biorender.com/).

\section{Authors' contributions}

All authors listed have made a substantial, direct and intellectual contribution to the work, read and approved the final manuscript. All authors read and approved the final manuscript.

\section{Funding}

The work was supported by a project funded by Jiangsu Health and Family Planning Commission (Z2018017), and a project funded by the Priority Academic Program Development of Jiangsu Higher Education Institutions (PAPD).

\section{Availability of data and materials}

Not applicable.

\section{Declarations}

Ethics approval and consent to participate Not applicable.

\section{Consent for publication}

Not applicable.

\section{Competing interests}

The authors declare that they have no conflict of interest.

\section{Author details}

${ }^{1}$ Jiangsu Key Laboratory of Immunity and Metabolism, Department of Pathogenic Biology and Immunology, Xuzhou Medical University, Xuzhou 221004, Jiangsu, China. ${ }^{2}$ Imaging Department, The Second Affiliated Hospital of Shandong First Medical University, Taian, Shandong, China. ${ }^{3}$ Department of Infectious Diseases, The Affiliated Hospital of Xuzhou Medical University, Xuzhou, Jiangsu, China. ${ }^{4}$ National Demonstration Center for Experimental Basic Medical Sciences Education, Xuzhou Medical University, Xuzhou, Jiangsu, China.

Received: 12 April 2021 Accepted: 25 June 2021

Published online: 06 August 2021

\section{References}

1. Karakousis ND, Papatheodoridi A, Chatzigeorgiou A, Papatheodoridis G. Cellular senescence and hepatitis B-related hepatocellular carcinoma: an intriguing link. Liver Int. 2020;40:2917-27.

2. Quasdorff M, Protzer U. Control of hepatitis B virus at the level of transcription. J Viral Hepat. 2010;17:527-36.

3. Bruce JIE, James AD. Targeting the calcium signalling machinery in cancer. Cancers (Basel). 2020;12(9):2351.

4. Patergnani S, Danese A, Bouhamida E, Aguiari G, Previati M, Pinton $P$, Giorgi C. Various aspects of calcium signaling in the regulation of apoptosis, autophagy, cell proliferation, and cancer. Int J Mol Sci. 2020;21(21):8323.

5. Ardura JA, Alvarez-Carrion L, Gutierrez-Rojas I, Alonso V. Role of calcium signaling in prostate cancer progression: effects on cancer hallmarks and bone metastatic mechanisms. Cancers (Basel). 2020;12(5):1071.

6. Apaire-Marchais V, Ogliastro M, Chandre F, Pennetier C, Raymond V, Lapied B. Virus and calcium: an unexpected tandem to optimize insecticide efficacy. Environ Microbiol Rep. 2016;8:168-78.

7. Xia W, Shen Y, Xie H, Zheng S. Involvement of endoplasmic reticulum in hepatitis B virus replication. Virus Res. 2006;121:116-21.

8. Bouchard MJ, Wang LH, Schneider RJ. Calcium signaling by HBx protein in hepatitis B virus DNA replication. Science. 2001;294:2376-8.

9. Oh JC, Jeong DL, Kim IK, Oh SH. Activation of calcium signaling by hepatitis B virus- $X$ protein in liver cells. Exp Mol Med. 2003;35:301-9.

10. Casciano JC, Bouchard MJ. Hepatitis B virus X protein modulates cytosolic $\mathrm{Ca}(2+)$ signaling in primary human hepatocytes. Virus Res. 2018;246:23-7.

11. Yang B, Bouchard MJ. The hepatitis B virus X protein elevates cytosolic calcium signals by modulating mitochondrial calcium uptake. J Virol. 2012;86:313-27.

12. Casciano JC, Duchemin NJ, Lamontagne RJ, Steel LF, Bouchard MJ. Hepatitis $B$ virus modulates store-operated calcium entry to enhance viral replication in primary hepatocytes. PLoS ONE. 2017;12:e0168328.

13. Yao JH, Liu ZJ, Yi JH, Wang J, Liu YN. Hepatitis B virus X protein upregulates intracellular calcium signaling by binding $\mathrm{C}$-terminal of orail protein. Curr Med Sci. 2018;38:26-34.

14. Chami M, Ferrari D, Nicotera P, Paterlini-Brechot P, Rizzuto R. Caspasedependent alterations of $\mathrm{Ca} 2+$ signaling in the induction of apoptosis by hepatitis B virus X protein. J Biol Chem. 2003:278:31745-55.

15. Loncke J, Kaasik A, Bezprozvanny I, Parys JB, Kerkhofs M, Bultynck G. Balancing ER-mitochondrial $\mathrm{Ca}(2+)$ fluxes in health and disease. Trends Cell Biol. 2021;S0962-8924(21):00028-33.

16. Deniaud A, Sharafeldein O, Maillier E, Poncet D, Kroemer G, Lemaire C, Brenner C. Endoplasmic reticulum stress induces calcium-dependent permeability transition, mitochondrial outer membrane permeabilization and apoptosis. Oncogene. 2008;27:285-99.

17. Cho HK, Cheong KJ, Kim HY, Cheong J. Endoplasmic reticulum stress induced by hepatitis $B$ virus $X$ protein enhances cyclo-oxygenase 2 expression via activating transcription factor 4 . Biochem $\mathrm{J}$. 2011:435:431-9.

18. Lee H, Kim H, Lee SA, Won YS, Kim HI, Inn KS, Kim BJ. Upregulation of endoplasmic reticulum stress and reactive oxygen species by naturally occurring mutations in hepatitis B virus core antigen. J Gen Virol. 2015:96:1850-4.

19. Choi YM, Lee SY, Kim BJ. Naturally occurring hepatitis B virus mutations leading to endoplasmic reticulum stress and their contribution to the progression of hepatocellular carcinoma. Int J Mol Sci. 2019;20(3):597. 
20. Geng X, Harry BL, Zhou Q, Skeen-Gaar RR, Ge X, Lee ES, Mitani S, Xue $D$. Hepatitis $B$ virus $X$ protein targets the $B C l-2$ protein CED-9 to induce intracellular $\mathrm{Ca} 2+$ increase and cell death in Caenorhabditis elegans. Proc Natl Acad Sci U S A. 2012;109:18465-70.

21. Distelhorst CW. Targeting BCl-2-IP3 receptor interaction to treat cancer: a novel approach inspired by nearly a century treating cancer with adrenal corticosteroid hormones. Biochim Biophys Acta Mol Cell Res. 2018;1865:1795-804.

22. Bonilla Guerrero R, Roberts LR. The role of hepatitis B virus integrations in the pathogenesis of human hepatocellular carcinoma. J Hepatol. 2005:42:760-77.

23. Huang J, Zhao L, Yang P, Chen Z, Ruan XZ, Huang A, Tang N, Chen Y. Fatty acid translocase promoted hepatitis $B$ virus replication by upregulating the levels of hepatic cytosolic calcium. Exp Cell Res. 2017;358:360-8.

24. Lin HJ, Ku KL, Lin IH, Yeh CC. Naringenin attenuates hepatitis B virus $X$ protein-induced hepatic steatosis. BMC Complement Altern Med. 2017; 17:505.

25. Chen X, Cao R, Zhong W. Host calcium channels and pumps in viral infections. Cells. 2019;9(1):94

26. Yen TT, Yang A, Chiu WT, Li TN, Wang LH, Wu YH, Wang HC, Chen L, Wang WC, Huang W, et al. Hepatitis B virus PreS2-mutant large surface antigen activates store-operated calcium entry and promotes chromosome instability. Oncotarget. 2016;7:23346-60.

27. Chami M, Gozuacik D, Saigo K, Capiod T, Falson P, Lecoeur H, Urashima T, Beckmann J, Gougeon ML, Claret M, et al. Hepatitis B virus-related insertional mutagenesis implicates SERCA1 gene in the control of apoptosis. Oncogene. 2000;19:2877-86.

28. Pathak T, Trebak M. Mitochondrial $\mathrm{Ca}(2+)$ signaling. Pharmacol Ther. 2018;192:112-23.

29. Rahmani Z, Huh KW, Lasher R, Siddiqui A. Hepatitis B virus X protein colocalizes to mitochondria with a human voltage-dependent anion channel, HVDAC3, and alters its transmembrane potential. J Virol. 2000;74:2840-6.

30. McClain SL, Clippinger AJ, Lizzano R, Bouchard MJ. Hepatitis B virus replication is associated with an $\mathrm{HBx}$-dependent mitochondrion-regulated increase in cytosolic calcium levels. J Virol. 2007;81:12061-5.

31. Tsukuda S, Watashi K. Hepatitis B virus biology and life cycle. Antiviral Res. 2020;182:104925.

32. Kong $F$, You $H$, Kong $D$, Zheng $K$, Tang $R$. The interaction of hepatitis $B$ virus with the ubiquitin proteasome system in viral replication and associated pathogenesis. Virol J. 2019;16:73.

33. Cho HK, Kim SY, Yoo SK, Choi YH, Cheong J. Fatty acids increase hepatitis $B$ virus $X$ protein stabilization and $\mathrm{HBx}$-induced inflammatory gene expression. FEBS J. 2014;281:2228-39.
34. Bouchard MJ, Wang L, Schneider RJ. Activation of focal adhesion kinase by hepatitis $B$ virus $H B x$ protein: multiple functions in viral replication. J Virol. 2006;80:4406-14.

35. Gearhart TL, Bouchard MJ. Replication of the hepatitis B virus requires a calcium-dependent HBx-induced G1 phase arrest of hepatocytes. Virology. 2010;407:14-25.

36. Gearhart TL, Bouchard MJ. The hepatitis B virus X protein modulates hepatocyte proliferation pathways to stimulate viral replication. J Virol. 2010;84:2675-86.

37. Yue X, Wang H, Zhao F, Liu S, Wu J, Ren W, Zhu Y. Hepatitis B virusinduced calreticulin protein is involved in IFN resistance. J Immunol. 2012;189:279-86

38. Choi Y, Gyoo Park S, Yoo JH, Jung G. Calcium ions affect the hepatitis B virus core assembly. Virology. 2005;332:454-63.

39. Choi J, Chang JS, Song MS, Ahn BY, Park Y, Lim DS, Han YS. Association of hepatitis B virus polymerase with promyelocytic leukemia nuclear bodies mediated by the $\mathrm{S} 100$ family protein p11. Biochem Biophys Res Commun. 2003;305:1049-56.

40. Peng Z, Fang G, Peng F, Pan Z, Su Z, Tian W, Li D, Hou H. Effects of Rubiadin isolated from Prismatomeris connata on anti-hepatitis $B$ virus activity in vitro. Phytother Res. 2017;31:1962-70.

41. Bouchard MJ, Puro RJ, Wang L, Schneider RJ. Activation and inhibition of cellular calcium and tyrosine kinase signaling pathways identify targets of the HBx protein involved in hepatitis B virus replication. J Virol. 2003;77:7713-9.

42. Xiao Y, Liu C, Tang W, Zhang H, Chen X. Evans blue inhibits HBV replication through a dual antiviral mechanism by targeting virus binding and capsid assembly. Front Microbiol. 2019;10:2638.

43. Watashi K, Sluder A, Daito T, Matsunaga S, Ryo A, Nagamori S, Iwamoto M, Nakajima S, Tsukuda S, Borroto-Esoda K, et al. Cyclosporin A and its analogs inhibit hepatitis B virus entry into cultured hepatocytes through targeting a membrane transporter, sodium taurocholate cotransporting polypeptide (NTCP). Hepatology. 2014;59:1726-37.

44. Zhang L, Liu C, Xiao Y, Chen X. Oxethazaine inhibits hepatitis B virus capsid assembly by blocking the cytosolic calcium-signalling pathway. J Gen Virol. 2016;97:1198-209.

\section{Publisher's Note}

Springer Nature remains neutral with regard to jurisdictional claims in published maps and institutional affiliations.
Ready to submit your research? Choose BMC and benefit from:

- fast, convenient online submission

- thorough peer review by experienced researchers in your field

- rapid publication on acceptance

- support for research data, including large and complex data types

- gold Open Access which fosters wider collaboration and increased citations

- maximum visibility for your research: over $100 \mathrm{M}$ website views per year

At BMC, research is always in progress.

Learn more biomedcentral.com/submissions 